\title{
Tourists, Expatriates and International Retirees: An Empirical Evidence from Malaysia
}

\author{
Chuie-Hong $\operatorname{Tan}^{1}$, Sin-Ban $\mathrm{Ho}^{2}$ \\ ${ }^{1}$ Faculty of Management, Multimedia University, 63100 Cyberjaya, Selangor, Malaysia \\ ${ }^{2}$ Faculty of Computing and Informatics, Multimedia University, 63100 Cyberjaya, Selangor, Malaysia
}

\begin{abstract}
Malaysia relies heavily on tourism industry to spur its economic growth. Parallel to the growth of tourists, Malaysia is also a popular destination for international retiree migration through the Malaysia My Second Home (MM2H) programme and expatriates. Hence this study attempts to investigate the relationship between tourists, expatriates and MM2H participants. The pull factors of Malaysia as a destination of tourism, expatriates and international retirees are prevalent, and could be further supported through analysis of the relationship between the three variables. This study employs secondary data from 1998 to 2012. Several methods of analysis are used to analyse the data, such as Unit Root Test, Co-integration Test and Granger Causality Test. The findings show that there is a unidirectional relationship between expatriates and MM2H participants. Public and private sectors need to cooperate to attract more expatriates in order to create the pull of MM2H participants. Meanwhile, tourism development policy must be improved to retain Malaysia as a premier destination for foreigners to work, live and relax.
\end{abstract}

\section{Introduction}

Tourism industry has become Malaysia largest growing industries in the past decades. This sector generates income to the country's economic growth [1,2], that entails the government to support the industry. Malaysia Tourism Board, a government agency that is given a responsibility to promote Malaysia as a premier destination in the world. Marketing representative offices are located abroad in United Kingdom (UK), USA, Japan, China etc. Worldwide marketing campaign such as "Visit Malaysia Years" is a great success that brought in over 7.4 millions tourists in 1999 and 20 millions in 2007.

The increasing number of retirees has stimulated the development of international retirement migration [3]. International retirement migration is a type of human movement of elderly people [4] to places of better quality life [5].

'Silver Hair' programme is introduced in 1996 to promote the Malaysia as a destination place for foreigners to retire. In 2002, this programme was renamed as 'Malaysia My Second Home' (MM2H) to encourage foreigners to own properties and live in Malaysia. MM2H has a more open-minded policy as compared to the 'Silver Hair' programme. In 2009, foreigners below the age of 50 are allowed to apply for MM2H. MM2H has also attracted foreign investments and spurred the growth of tourism, health and education sectors. 
Tourism's roles in supporting retirement migration are prevalent in past researches [5-8]. A foreigner, as a tourist, may have visited places and may stimulate an interest to settle down in the host destination [9]. Thus, this sort of experience could be felt by a tourist or expatriate who has spent an amount of time travelling and working in the destination country. Asian expatriate, a potential retiree gets accustomed to the host's environment.

Malaysia is also an important destination for expatriates to work and live in particularly from South Asia. The number of expatriates has been increasing recently parallel to the number of $\mathrm{MM} 2 \mathrm{H}$ retirees. Thus, this research is conducted to study the relationship between the three variables, tourists, expatriates and $\mathrm{MM} 2 \mathrm{H}$ retirees. As Malaysia government actively promotes $\mathrm{MM} 2 \mathrm{H}$ programme, these results provide important insights to form the policies of future international retirement migration.

Next, in Section 2, the paper reviews the tourists, international retirement migration and expatriates past research. Section 3 describes the data and methodology employed in the study. The empirical findings and discussion precede the concluding remarks.

\section{Literature Review}

\subsection{Tourist}

Today, tourism is the most dynamic economic sector in the world. Tourism generates income and contributes majorly to Malaysia economic country. Tourism will attract more foreign travel, such as business travels when the destination country becomes more well-known. This will ultimately leads to an increase in settlement in the host country, hence indirectly increase the number of expatriates working and also MM2H applicants. Dayang Hummida et al. [2] explored the role of tourism in Malaysia economic growth. Their study shows that there was a positive relationship between tourist and Malaysia economic growth.

\section{2 'Malaysia My Second Home’ (MM2H)}

In 1996, retirement opportunities are offered by Malaysia to non-Malaysian nationals with the 'Silver Hair' programme. However, in order to attract a younger high net worth individuals, 'Malaysia My Second Home' (MM2H) programme was presented in 2002. MM2H programme provides a path for financially independent foreigners to choose a retirement life in Malaysia [10]. The programme has encouraged foreigners, their spouses and dependants to choose Malaysia as their second home.

Malaysia is ranked fourth in 2012 Retirement Index [11]. Malaysia is positioned after Ecuador, Panama and Mexico. International Living, 2011 quotes that Malaysia is the best place to retire in Asia. To date, the MM2H programme had attracted a total of 21,059 participants during the year $2002-$ 2012. Among them are nationals from China which comprised 17.9 per cent of the total, followed by Japan at 12.4 per cent, Bangladesh at 11.9 per cent, United Kingdom at 9.2per cent, Iran at 5.9 per cent, Singapore at 4.3 per cent, Taiwan at 3.9 per cent, Pakistan at 3.8 per cent, Republic of Korea at 3.4 percent, India at 3.3 percent, and others at 23.8 percent [12]. The programme is anticipated to stimulate foreign income to economy in Malaysia through tourism, property development, health, and education industry.

\subsection{Expatriates}

Malaysia is an important destination country for expatriates, particularly from South Asia and East Asia. Its political stability, better infrastructure and consistent economic growth create a pull of expatriates towards the country. In 2012, statistics gathered from Malaysia Immigration Department show that there were 61,113 expatriates applying for the employment pass in Malaysia. About 21.1 per cent were from India, 11.9 percent were from ASEAN countries, 10.4 percent were from China, 6.4 and 5.2 percent were from Japan and United Kingdom, respectively. The others are from Republic 
of Korea (3.7 per cent), Australia and New Zealand (3.4 per cent), United States of America (2.6 per cent), Continental Europe (2.2 per cent) and Taiwan (1.6 per cent).

Generally, not much research is done to investigate the linkages between the expatriates and international retirement migration in developed or developing countries. Most of the previous studies focus more on investigating the contribution of tourism industries to economic growth in Malaysia [13]. Abdul-Rashid et al. [14] studies factors that attracts and distracts foreign retirees to reside in Malaysia by using qualitative survey. They found that retirees in host destination also influence migration decisions of strangers, particularly expatriates. Ono [6] discovered that aspects such as cost of living, weather, entertainment opportunities, visa systems and elderly care facilities are positive inducement for Japanese retirees to live in Malaysia.

\subsection{International retirement migration, tourists and expatriates}

Wiseman [15] and Schiamberg et al. [16] found that retirement migration is stimulated by elements, like personal resources and their characteristics, social factors and support networks. Haas and Seron [17] developed a retirement migration model and suggested that a difference between distant thoughts stimulated by migration experience and contemplation of choices. They also discovered that the migration decision and locality choice are mutually matching and coinciding decisions. However, the flaw of the migration model is the inability to depict the environmental practice that involves retirees' past working life.

International retirement migration (IRM) adds intricacy to the migration model [18] in predicting retirees' movements and their effect on the real estate supply and demand. Liebman [19] discovered that globalization also assists a free mobility of people around the world. IRM is the professionals' plan to retire after their working life [20]. The migration may happen as transitory and voluntary. It depends on past tourist experiences, working life experiences, the duration spent in the host destination and the real estate owned [21-22]. Retirement destinations usually coincide with tourist destinations [20] and possibly working destination. Retirement migration is identified as a type of tourism-informed mobility [3] and expatriate-informed mobility in this study.

Positive life experiences such as relaxed and freedom activity [5, 23], peaceful environment [24], are thoughts that can trigger retirement migration. Repeated working and travelling experiences may create emotional affection among potential retirees through a sense of acquaintance and social contacts with the host country. Some foreigners, particularly expatriates consider retiring and buying a second home [25] and living in the host destination where the expatriates used to experience everyday life.

Malaysia is a popular choice for second home, besides Spain [20] [25], Turkey [5], and Mexico [26]. The increase in the number of foreign retirees in Malaysia raises questions regarding the causal relation between the number of expatriates and number of international retirement migration in Malaysia.

This study applied the double-log bivariate model to examine the relationship between tourists, expatriates and MM2H participants. The following are the hypotheses suggested:

H1: Expatriates do not attract MM2H participants.

$\mathrm{H} 2$ : MM2H participants do not attract MM2H participants.

$\mathrm{H} 3$ : Tourists do not attract MM2H participants.

$\mathrm{H} 4$ : MM2H participants do not attract tourists.

The following section discusses data and methodology of the study.

\section{Data and Analysis of the Results}

This study evaluates the causality relationship existence between number of tourist arrivals, number of expatriates and number of MM2H participants in Malaysia. The series of annual data from year 2002 to 2012 are obtained from the Malaysia Immigration Department and Malaysia Tourism Board. 
To test the association between the variables while avoiding spurious correlation, the study follow three steps in the empirical analysis. First, unit root tests were analyzed to check the stationary and the order of the series variables by using the Augmented Dickey-Fuller, ADF [27] and Phillips-Perron, PP [28].

Second, a long-run relationship between variables uses the ARDL co-integration procedure as proposed by Pesaran et al. [29]. The ARDL bounds testing approach are given as follow:

$$
\begin{aligned}
& \Delta \ln Y_{t}=a_{0 Y}+\sum_{i=1}^{n} b_{i Y} \Delta \ln Y_{t-i}+\sum_{i=1}^{n} c_{i Y} \Delta \ln X_{t-i}+\sigma_{1 Y} \ln Y_{t-i}+\sigma_{2 Y} \ln X_{t-i}+\varepsilon_{\mathrm{Y}_{\mathrm{t}}} \\
& \Delta \ln X_{t}=a_{0 X}+\sum_{i=1}^{n} b_{i X} \Delta \ln X_{t-i}+\sum_{i=1}^{n} c_{i X} \Delta \ln Y_{t-i}+\omega_{1 X} \ln X_{t-i}+\omega_{2 X} \ln Y_{t-i}+\varepsilon_{\mathrm{X}_{t}}
\end{aligned}
$$

In equation 1 and 2, $\Delta$ is the difference, $Y_{t}$ is the $i$ number of MM2H participants, $X_{t}$ is the $i$ number of expatriates or number of tourist arrivals, $a_{O Y}$ and $a_{O X}$ are the drift component, while $\varepsilon_{\mathrm{X}_{\mathrm{t}}}$ and $\varepsilon_{\mathrm{Y}_{\mathrm{t}}}$ are white noise errors. Pesaran et al. [29] provide two sets of asymptotic critical values for the $\mathrm{F}$ test. One set assumes that all the variable are $I(0)$ and another assumes they are all $I(1)$. The null hypothesis of the non-existence of a long-run relationship, denoted by $H_{0}: \sigma_{1 Y}=\sigma_{2 Y}=0$. If the test statistic is higher than the upper bound critical value, the null of no co-integration is rejected in favour of the existence of a long-run relationship. On the other hand, if the test statistic is below the lower critical value, it implies the absence of co-integration. If the statistics full within their respective bounds, there is no conclusive reference. In this case, prior information about the order of integration of the variable is required to decide on long-run relationships.

However, co-integration implies that causality exists between the series but it does not mention the direction of the causal relationship. In the third step, Granger causality test in the long-run relationship is tested. The error correction models of co-integration are used to examine the short run causality between the number of expatriates and the number of $\mathrm{MM} 2 \mathrm{H}$ participants or number of tourists and the number of MM2H participants. Thus, error correction model can be specified as follow:

$$
\begin{aligned}
& \Delta \ln Y_{t}=a_{0}+\partial E C T_{t-1}+\sum_{k=1}^{p} a_{1 k} \Delta \ln Y_{t-k}+\sum_{k=1}^{q} a_{2 k} \Delta \ln X_{t-k}+e_{1 \mathrm{t}} \\
& \Delta \ln X_{t}=b_{0}+\partial E C T_{t-1}+\sum_{k=1}^{r} b_{1 k} \Delta \ln X_{t-k}+\sum_{k=1}^{s} b_{2 k} \Delta \ln Y_{t-k}+e_{2 \mathrm{t}}
\end{aligned}
$$

where $\ln$ is the natural logarithm, $\Delta$ is the first difference operator, $Y_{t}$ is the $i$ number of MM2H participants, and $X_{t}$ is the $i$ number of expatriates or number of tourists. $E C T_{t-1}$ is $\log$ error correction term derived from long run co-integration model. $e_{1 t}$ and $e_{2 t}$ are serially independent random error with mean zero and finite covariance matrix.

\section{Empirical Results}

Table 1 presents the results of the unit root tests. The ADF statistics indicates all the three variables are stationary after first differencing. In other words, the variables are integrated of order (1). This result is consistent to the finding of Nelson and Plosser [30] that most of the macroeconomic variables are non-stationary at level, but they are stationary after first differencing. With the result of the uniform $I(1)$ process, the presence of long-run equilibrium relationship between variables is examined in the next stage using co-integration test. To reject the null hypothesis of no co-integration, the trace statistic must be greater than critical value. 


\section{ICTR}

Table 1. Unit root test results for expatriates and MM2H participants for the $2002-2012$ period.

\begin{tabular}{|c|c|c|c|c|c|}
\hline Series & Level & Prob. & $\begin{array}{c}\text { First } \\
\text { Difference }\end{array}$ & Prob. & Result \\
\hline Expatriates: & -1.254 & 0.6058 & -3.038 & $0.0684 *$ & $I(1)$ \\
\hline Tourists: & -2.905 & 0.2681 & -3.183 & $0.0449^{*}$ & $I(1)$ \\
\hline MM2H participants: & -2.327 & 0.1821 & -2.909 & $0.0821^{*}$ & $I(1)$ \\
\hline
\end{tabular}

Note: * indicates significance at $10 \%$ level.

Table 2 reports the Johansen co-integration trace test statistic. The test results indicate that the null hypothesis of no co-integration between expatriates and $\mathrm{MM} 2 \mathrm{H}$ participants has been rejected at 5 percent significance level. Thus, it can be interpreted that there is a co-integrating relationship between expatriate and $\mathrm{MM} 2 \mathrm{H}$ participants.

Table 2. Co-integration test for expatriates and MM2H for the $2002-2012$ period.

\begin{tabular}{ccccc}
\hline \hline Variables & Null hypothesis & Trace test & $\begin{array}{c}95 \% \text { critical } \\
\text { value }\end{array}$ & Prob. \\
\hline \hline Expatriates & $r=0$ & $18.351^{* *}$ & 15.495 & 0.0181 \\
\hline MM2H participants & $r \leq 1$ & $6.031^{* *}$ & 3.842 & 0.0141 \\
\hline \hline
\end{tabular}

Note: $* *$ indicates significance at $5 \%$ level.

In Table 3 the test results indicate that the null hypothesis of no co-integration between tourists and $\mathrm{MM} 2 \mathrm{H}$ participants has also been rejected at 5 percent significance level. Thus, it can be interpreted that there is a co-integrating relationship between tourists and $\mathrm{MM} 2 \mathrm{H}$ participants.

Table 3. Co-integration test for tourists and MM2H for the $2002-2012$ period.

\begin{tabular}{ccccc}
\hline \hline Variables & Null hypothesis & Trace test & $\begin{array}{c}95 \% \text { critical } \\
\text { value }\end{array}$ & Prob. \\
\hline \hline Tourists & $r=0$ & $29.359^{* *}$ & 15.495 & 0.0002 \\
\hline MM2H participants & $r \leq 1$ & $4.371^{* *}$ & 3.842 & 0.0365 \\
\hline \hline
\end{tabular}

Note: $* *$ indicates significance at $5 \%$ level. 
Given that the variables are co-integrated, Granger causality test between the number of expatriates and $\mathrm{MM} 2 \mathrm{H}$ participants as well as the number of tourists and $\mathrm{MM} 2 \mathrm{H}$ participants is performed separately based on VECM (Vector Error Correction Model).

Table 4. Pair-wise Granger causality test results between expatriates and MM2H participants.

\begin{tabular}{cccccc}
\hline \hline & $\begin{array}{c}\mathrm{H}_{0} \text { : Expatriates do not Granger } \\
\text { cause MM2H participants }\end{array}$ & & \multicolumn{2}{c}{$\begin{array}{c}\mathrm{H}_{0} \text { : MM2H participants do not } \\
\text { Granger cause expatriates }\end{array}$} \\
\cline { 3 - 5 } Lag & F-statistic & p-value & & F-statistic & p-value \\
\hline \hline & 5.895 & $0.0456^{* *}$ & 0.829 & 0.3929 \\
\hline \hline
\end{tabular}

Note: ** indicates significance at $5 \%$ level.

Table 5. Pair-wise Granger causality test results between tourists and MM2H participants.

\begin{tabular}{cccccc}
\hline \hline & $\begin{array}{c}\mathrm{H}_{0} \text { : Tourists do not Granger } \\
\text { cause MM2H participants }\end{array}$ & & \multicolumn{2}{c}{$\begin{array}{c}\mathrm{H}_{0} \text { : MM2H participants do not } \\
\text { Granger cause tourists }\end{array}$} \\
\cline { 5 - 6 } Lag & F-statistic & p-value & & F-statistic & p-value \\
\hline \hline & 0.035 & 0.8571 & 3.415 & 0.1071 \\
\hline \hline
\end{tabular}

Note: ** indicates significance at $5 \%$ level.

Table 4 and Table 5 present the pair-wise Granger causality test results between the expatriates and $\mathrm{MM} 2 \mathrm{H}$ participants and also between tourists and $\mathrm{MM} 2 \mathrm{H}$ participants. In Table 4, the results indicate that the null hypothesis that expatriates do not Granger cause MM2H participants is rejected at the 5 percent significance level. On the other hand, the null hypothesis that MM2H participants do not Granger cause expatriates is accepted at the 5 percent significance level. These findings imply that the volume of expatriates plays an important role attracting the number of $\mathrm{MM} 2 \mathrm{H}$ participants. In Table 5, both null hypotheses are not significant at 5 percent level. This shows that tourists do not significantly attract MM2H participants.

\section{Conclusion}

This paper investigates the presence of Granger causality and co-integrated relationships between tourists, expatriates and $\mathrm{MM} 2 \mathrm{H}$ participants in Malaysia using panel co-integration techniques from 2002-2012. The results of panel co-integration tests suggest that there is a co-integrated relationship between tourists, expatriates and MM2H participants. The findings of Granger Causality in VECM framework indicate that there is a unilateral causality between expatriate and MM2H participants in which that the variable expatriates in Malaysia have a positive relationship with MM2H participants. In other words, an increase in number of expatriates in Malaysia led to increase in the number of MM2H participants. 
The significant impact of expatriates in promoting $\mathrm{MM} 2 \mathrm{H}$ programme justifies the importance of public and private involvement by executing various policies, such as government giving incentives to expatriates in order to pull their potential MM2H participants to Malaysia. Malaysia policy makers should recognise the tie between Malaysia as a business and leisure attractions, and retirement place. Proceedings for the issuance of employment pass and $\mathrm{MM} 2 \mathrm{H}$ application approval must be expedited and improved.

A strategy involves consumer marketing, adopting the positive pull, and commercial attributes of Malaysia is required to attract the inflow of expatriates to Malaysia. These include affordable living cost, warm climate, friendly locals, stress-free immigration and retirement system, political stability and security. Environmental and socio cultural should be integrated into national policies to enhance the image of Malaysia as a beautiful and peaceful country to live in and work. Tourism activities could be considered in promoting the inflow of expatriates, and hence attract the number of MM2H participants. Inter-ministerial committees should be developed to representatives from the tourism industry, immigration department in order to coordinate and monitor the implementation of the MM2H programme successfully.

\section{References}

1. C. F. Tang, Int. J. of Tourism Research, 13, 97-101 (2011)

2. A. R., Dayang-Hummida, A. M. Dayang-Affizzah, Salbiah Edman, GBSR e-Journal of Business, Economics and Social Sciences Research 2013

3. A. M. Williams, C. M. Hall, Tourism and Migration: New Relationship Between Production and Consumption, pp. 1-60, London: Kluwer Academic Publishers (2002)

4. A. M. Williams, R. King, T. Warnes, European Urban and Regional Studies, 4,2, 115-134 (1997)

5. C. Balkir and B. Kirkulak, H. Fassmann, Migration and Mobility in Europe: Trends, Patterns and Control, pp. 123-143, Cheltenham, UK: Edward Elgar Publishing (2009)

6. M. Ono, Transnational Migration in East Asia Senri Ethnological Reports, 77, 151-162 (2008)

7. M. A. Casado-Diaz, C. Kaiser, A. M. Warnes, Ageing and Society, 24,3, 353-381 (2006)

8. K. Claudia, ESA2009-9th Conference of European Sociological Association, Lisbon, Portugal, 25 September 2009

9. L. Cuba, Generations, 13, 63-67 (1989)

10. R. Ho and K. H. Teik, Penang Economic Monthly. Socio-economic \& Environmental Research Institute, 10,3, (2008)

11. International Living, Retrieved from http://internationalliving.com/2011/12/the-scores-and-howour-2012-retirement-index-works/_(2012).

12. MM2H Centre, Malaysia My Second Home (MM2H) Centre, Ministry of Tourism Malaysia. Available from: http://www.mm2h.gov.my (2014)

13. C. F. Tang, Int. J. of Tourism Research 13,1, 97-101 (2011)

14. A. Abdul-Aziz, C. L. Loh, M. Jaafar, Tourism Management, 40,1,203-212 (2014)

15. R. F. Wiseman, Research on Aging, 2, 141-154 (1980)

16. L. B. Schiamberg, V. Junk, K. Goldfarb, The Annual Meeting of the Gerontological Society of America, San Francisco (1991)

17. W. H. Haas, W. J. Serow, The Gerontologist, 33, 212-220 (1993)

18. K. M. Gibler, J. M. Casado-Diaz, M. A. Casado-Diaz, V. Rodriguez and P. Taltavull, Int. J. of Housing Markets and Analysis, 2, 2, 190-210 (2009)

19. G. Liebman, The Sociology of Tourism. Theoretical and Empirical Investigations, p. 358, London: Routledge (2002)

20. T. Breur, Die Erde, 136,3, 313-333 (2005)

21. K. O’Reilly, Tourist Studies, 3,3, 301-317 (2003)

22. R. King, A. M. Warnes, A. M. Williams, Sunset Lives. British Retirement Migration to the Mediterranean, Berg: Oxford (2000)

23. V. F. Rodrigues and F. Rojo, European Int. J. of Population Geography, 4,2, 183-200 (1998) 
24. P. Salva Tomas, 28th International Geographical Union Conference, 4-10 August 1996, the Hague, the Netherland (1996)

25. V. F. Rodrigues, F. Rojo, Population Review, 43,1, 1-36 (2004)

26. K. Brass, Retrieved from http://internationalpropertyjournal.com/blog/2010/08/13/225-mexicoremains-top-choice-for-us-second-home-owners.html. (2010)

27. D. A. Dickey, W. A. Fuller, Journal of American Association, 74, 427-431 (1979)

28. P. C. B. Phillips, P. Perron, Biometrica, 75, 335-446 (1988)

29. M. H. Pesaran, Y. Shin, R. J. Smith, Journal of Applied Econometrics, 16, 289-326 (2001)

30. C. R. Nelson, C. I. Plosser, Journal of Monetary Economics, 10,2, 139-162 (1982) 